\title{
Researches Regarding the Reduction of Oxidation Losses in the Obtaining of Secondary Aluminium Alloys Using Metallic Scraps
}

\author{
CONSTANTIN APOSTOL ${ }^{1}$, MIHAI BUTU1*, CRISTIAN DOBRESCU ${ }^{1}$, ALEXANDRA TACHE ${ }^{2}$ \\ ${ }^{1}$ Politehnica University of Bucharest, 313 Splaiul Independentei, 060042, Bucharest, Romania \\ ${ }^{2}$ S.C. AS METAL S.R.L, 104G Berceni Road, 041919, Bucharest, Romania
}

\begin{abstract}
The paper presents thermodynamic aspects regarding the low temperature processing of small metal waste - aluminum alloy scraps. The activation energies of oxidation reactions of aluminum and some alloying elements with water vapors, carbon dioxide and oxygen present inside the furnace are compared, at the usual and experimentally temperatures (at $580-620^{\circ} \mathrm{C}$, near the eutectic temperature, when the melt is in the semisolid/pasty state), in the elaborating of EN AB 46100 secondary alloys. The composition of the flue gases is presented at different temperatures and during different technological stages. Using electronic microscopy and EDS analysis, the elemental composition of the impurities resulted from the melt is highlighted.
\end{abstract}

Keywords: metallic scraps, secondary Al alloys, activation energy, oxidation

Conventional recycling techniques generate hazardous residue that usually requires disposal at a high cost. Aluminium slags contain $\mathrm{MgAl}_{2} \mathrm{O}_{4}, \mathrm{Al}_{2} \mathrm{O}_{3} \cdot \mathrm{FeO}$, calcium oxides, AlN, quartz $\left(\mathrm{SiO}_{2}\right), \alpha-\mathrm{Al}_{2} \mathrm{O}_{3}^{2}$, periclase ( $\left.\mathrm{MgO}\right)$, spinel $(\mathrm{Mg}, \mathrm{Si}) \mathrm{Al}_{2} \mathrm{O}$, chlorides $^{2}\left(\mathrm{AlCl}_{3}, \mathrm{NaCl}, \mathrm{KCl}\right)$, fluorides $\left(\mathrm{CaF}_{2}\right.$ $\mathrm{NaF}, \mathrm{AlF}_{3^{\prime}} \mathrm{Na}_{3} \mathrm{AlF}_{6}$ etc.) , carbides $\left(\mathrm{Al}_{4} \mathrm{C}_{3}\right)$, sulphides $\left(\mathrm{Al}_{2} \mathrm{~S}_{3^{\prime}}\right.$, $\mathrm{FeSO}_{3}$ ), phosphors, impurities, apart from metallic aluminium (between $80 \%$ and $20 \%$ ). By washing them with hot water the AIN compound can be transformed into $\mathrm{Al}(\mathrm{OH})_{3}$, which, in reaction with $\mathrm{Na}$ and $\mathrm{K}$ leads to the removal of chlorides from waste [1, 3, 8, 10, 13 -15].

By processing aluminium and aluminium alloy scraps with the usual techniques, the loss of aluminium can easily reach $50 \%$, traditional recovery procedures becoming ineffective. In paper [2] studies are presented regarding a new aluminium recovery process by treating the black slag, (ABD - Al black dross), a by-product formed during aluminium scraps melting.

Six major phases have been identified: spinel ( $\mathrm{MgAl}_{2} \mathrm{O}_{4}$, aluminium nitride (AIN), diaoyudaoite $\left(\mathrm{NaAl}_{11} \mathrm{O}_{17}\right)$, aluminium oxynitride $\left(\mathrm{Al}_{5} \mathrm{O}_{6} \mathrm{~N}\right)$, halite $(\mathrm{NaCl})$ and corundum $\left(\mathrm{Al}_{2} \mathrm{O}_{3}\right)$. In addition, hibonite compounds $\left(\mathrm{CaAl}_{3} \mathrm{O}_{1}\right)$, calcium fluoride $\left(\mathrm{CaF}_{2}\right)$, calcite $\left(\mathrm{CaCO}_{3}\right)$ and sylvite $(\mathrm{KCl})$, are also present as minor constituents. $\mathrm{NaCl}, \mathrm{KCl}$ and $\mathrm{CaF}_{2}$ are compounds from the fluxes used to treat the melt in order to protect the metal from the reactive atmosphere in the furnace.

Corundum comes from the reaction of atmospheric oxygen with molten metallic aluminium at high temperatures. As reaction products, we also encounter nitrides due to the presence of nitrogen in the atmosphere of the furnace and due to the high temperatures at which the processes take place. $\mathrm{MgAl}_{2} \mathrm{O}_{4}$ is the result of oxidation of magnesium in aluminium waste, where it is present as an alloying element. The presence of $\mathrm{CaCO}_{3}$ compound can be explained by the reaction of $\mathrm{CaO}$ impurities in the raw material with $\mathrm{CO} / \mathrm{CO}_{2}$.

White slag can be reprocessed for the recovery of mechanically entrained aluminium or in compound form, black slag can be, and must be converted into environmentally friendly commercial products [4]. Slag processing can be done by acid solubilization [12] .
H.N. Yoshimura et al. and Apeng Li et al. have studied the possibility of using aluminium white slag to obtain a refractory material - High-alumina refractory (HAR), with the main crystalline phase $\mathrm{Al}_{2} \mathrm{O}_{3}$ and traces of $\mathrm{MgAl}_{2} \mathrm{O}_{4}$ and $\mathrm{CaAl}_{2} \mathrm{O}_{4}$, by replacing the materials currently used. They can be used in the production of ceramics, cement, in the construction of furnaces used in the metallurgy of nonferrous metals, the machine building industry and the defence industry, extending also in space and nuclear engineering $[5,6,11]$.

The production of $\eta$-alumina has also been studied to avoid environmental pollution and to obtain a material with special properties. The main advantages of this new material are corrosion resistance, thermal shock resistance, thermal stability and good refractory properties. Another great advantage is the lack of the need to store it, thus avoiding the pollution of the groundwater [7].

\section{Experimental part}

The raw material used in the experiments is aluminium chips, unprocessed, in accordance with national and international standards. This material is classified as conforming SR EN 13920-12 or 13, equivalent to ISRI TEENS (fig. 1) or TELIC (fig. 2) notations and consists of aluminum borings and turnings of one specified alloy (TEENS - the material must be free from oxides, dirt, free iron, stainless steel, magnesium, oils, flammable liquids, moisture and other non-metallic elements), or derived from two or more alloys (TELIC - the material must be clean, uncorroded aluminum borings and turnings of two or more alloys and subject to deductions for fines in excess of 3\% through a 20 mesh screen and dirt, free iron, oil, moisture and all other non-metallic items) [18].

This type of material does not always meet moisture or impurity requirements. This paper proposes a high humidity aluminium metallic scraps processing technology, with low values in terms of combustion losses-taking into account the dimensions of the particles.

In this study, it is intended to reintroduce into the industrial circuit small metallic waste (scraps) with high humidity in order to obtain a secondary standardized alloy. The removal of impurities from the melt will be done through fluxing treatment.

\footnotetext{
*email: mihaibutu@yahoo.com
} 


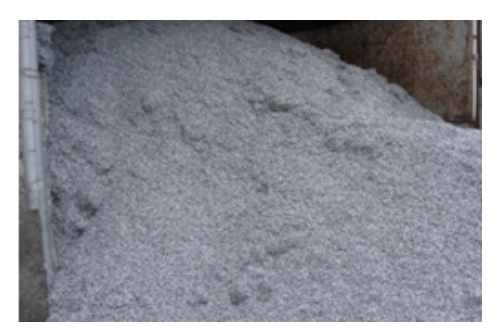

Fig. 1. ISRI TEENS

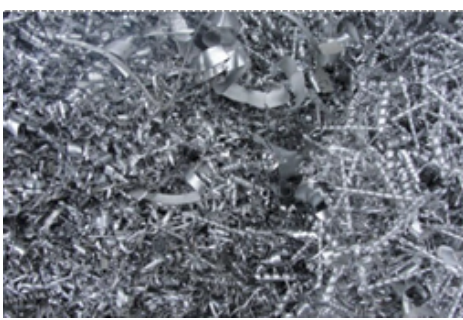

Fig. 2. ISRI TELIC

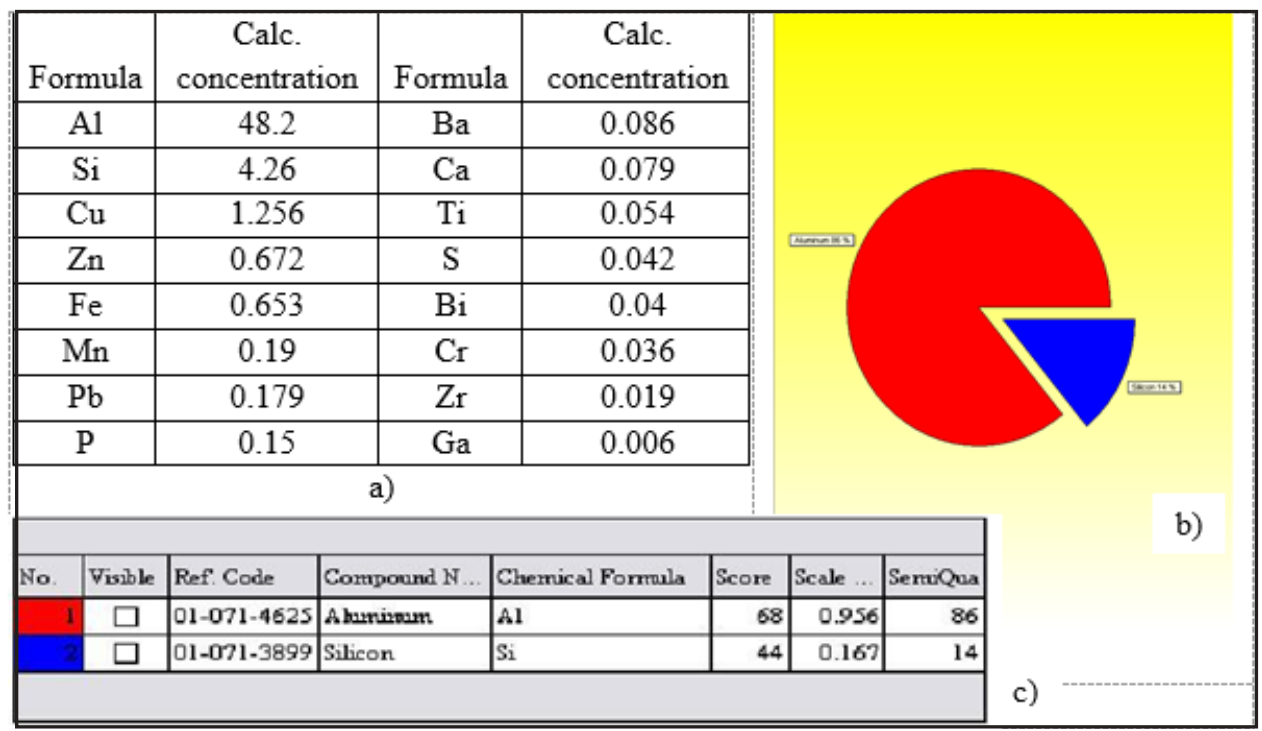

Fig. 3. The aluminium scraps analysis used in experiments

a) chemical composition;

b) and c) share of the main elements

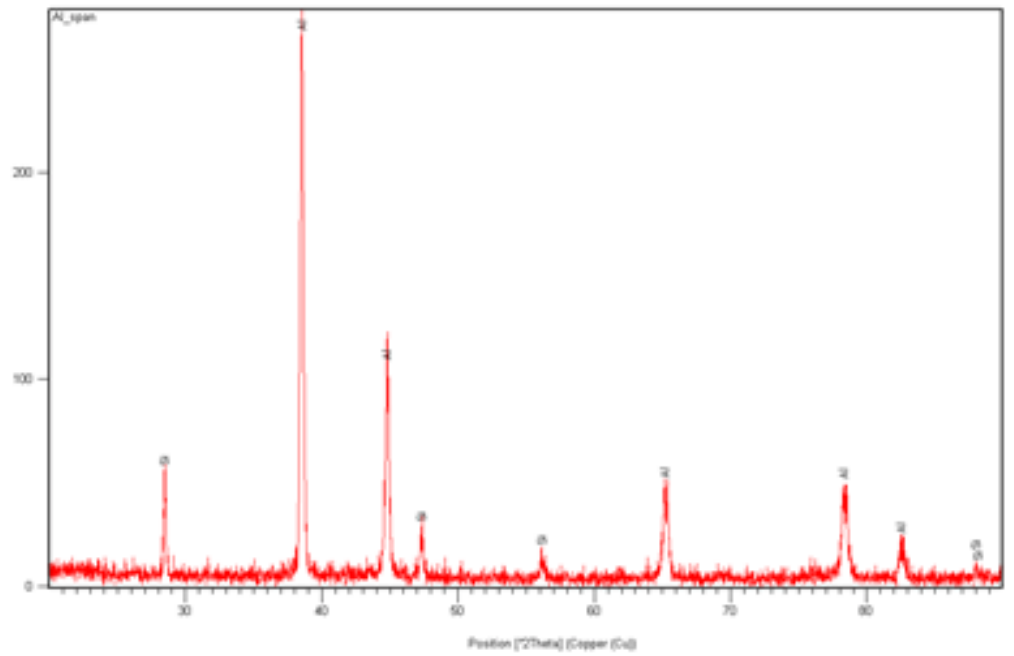

Fig. 4. Diffractogram of high-weight compounds in the analysed chord

The aluminium scraps used in the experiments were analysed by diffraction (fig. 3,4) to highlightits composition. Since the humidity in the material is very high, the results obtained (in percent) are not conclusive.

By combustion of methane gas in room-type furnaces, the flue gases come in direct contact with the raw material for preheating, heating and melting. Following the reactions that take place [16] mainly, the following reaction products are produced: $\mathrm{CO}, \mathrm{CO}_{2}, \mathrm{H}_{2}$ and $\mathrm{H}_{2} \mathrm{O}$. These gases, together with combustion oxygen, interact with the materials that form the charge, leading to the formation of a significant amount of slag, i.e. significant losses through oxidation.

In this article, the authors propose the processing of aluminium alloy castings to obtain low-temperature secondary alloy EN AB 46100 to reduce batch/load oxidation.

The choice of temperature was made based on the data from speciality literature (table 1) [17] but also of its own experiments.

Table 1

EUTECTIC TEMPERATURE OF SOME ALLOYS AI-Si-Cu [17]

\begin{tabular}{|c|c|c|c|c|c|c|c|c|}
\hline Alloy & $\mathrm{Si}$ & $\mathrm{Cu}$ & $\mathrm{Fe}$ & $\mathrm{Mg}$ & $\mathrm{Zn}$ & Rest, total & $\mathrm{Al}$ & T Eutectic, ${ }^{\circ} \mathrm{C}$ \\
\hline AA 319.0 & $\begin{array}{l}5,5- \\
6.5 \%\end{array}$ & $\begin{array}{l}3.0- \\
4.0 \%\end{array}$ & $c=1.0 \%$ & $<=0.1 \%$ & $<=1,0 \%$ & $c=1.60 \%$ & $\begin{array}{c}85.8- \\
89.9 \%\end{array}$ & $\begin{array}{l}562.3 \\
( \pm 2,3)\end{array}$ \\
\hline A.A 332.0 & $\begin{array}{c}8.8- \\
10.5 \%\end{array}$ & $\begin{array}{l}2.0- \\
4.0 \%\end{array}$ & $\tau=1.2 \%$ & $\begin{array}{l}0,50- \\
1.5 \%\end{array}$ & $\varepsilon=1,0 \%$ & $\varepsilon=0.50 \%$ & $\begin{array}{c}80.1- \\
88.7 \%\end{array}$ & $\begin{array}{c}557.4 \\
( \pm 6)\end{array}$ \\
\hline AA 333.0 & $\begin{array}{l}8.0- \\
10 \%\end{array}$ & $\begin{array}{l}3.0- \\
4.0 \%\end{array}$ & $\tau=1.0 \%$ & $\begin{array}{c}0.05- \\
0.50 \%\end{array}$ & $<=1.0 \%$ & $\tau=0.50 \%$ & $\begin{array}{l}81.8- \\
89 \%\end{array}$ & $\begin{array}{c}560.5 \\
( \pm 4)\end{array}$ \\
\hline A.A 383.0 & $\begin{array}{c}9.5- \\
11.5 \%\end{array}$ & $\begin{array}{l}2.0- \\
3.0 \%\end{array}$ & $\varepsilon=1.3 \%$ & $s=0.10 \%$ & $<=3.0 \%$ & $c=0.50 \%$ & $\begin{array}{c}79.7- \\
88.5 \%\end{array}$ & $\begin{array}{l}566.3 \\
( \pm 2.2)\end{array}$ \\
\hline AA 384.0 & $\begin{array}{l}10.5- \\
12 \%\end{array}$ & $\begin{array}{l}3.0- \\
4.5 \%\end{array}$ & $\kappa=1.3 \%$ & $<=0.10 \%$ & $<=3.0 \%$ & $<=0.50 \%$ & $\begin{array}{l}77.3- \\
86.5 \%\end{array}$ & $\begin{array}{l}561.3 \\
( \pm 3.2)\end{array}$ \\
\hline
\end{tabular}




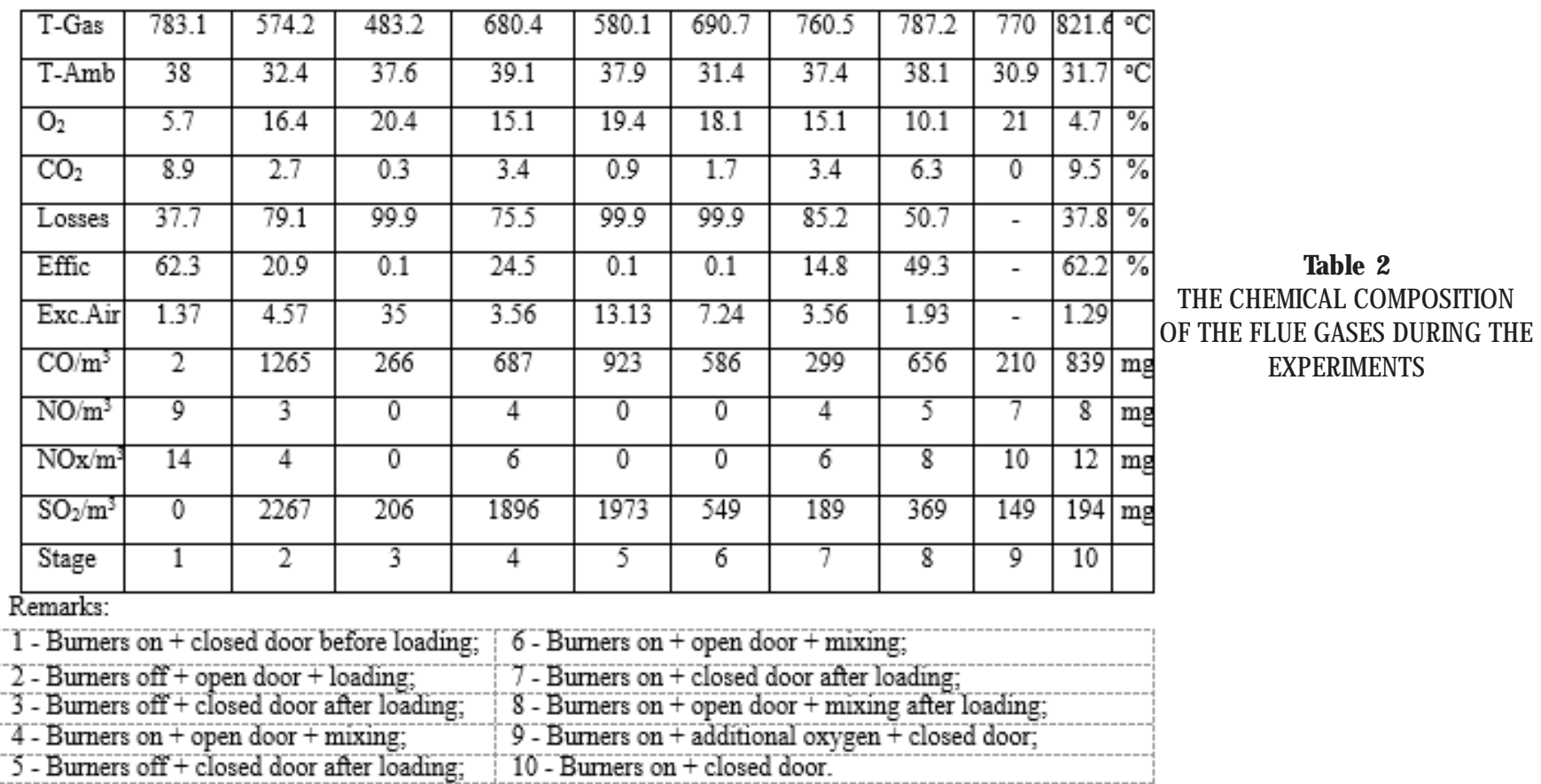

Based on the data in table 1 but also on our own experiments (EN AB 46100, 10.75\% Si, 1.81\% Cu, 1.34\% $\mathrm{Zn}, 0.93 \% \mathrm{Fe}, \mathrm{T}_{\text {eut }}=568^{\circ} \mathrm{C}$ ) it has been chosen that the working temperature, the temperature of the semisolid/ pasty metal material in the furnace, should fall within the limits of $580 \div 620^{\circ} \mathrm{C}$.

The experiment took place at SC AS Metal SRL, on a 16tonne furnace equipped with the oxy-fuel system. Flue gas samples were taken at different points in the process with DELTA 2000-IV apparatus, as can be seen from table 2.

Low-temperature processing reduces losses of oxidation for both aluminium and other metallic elements in the scraps composition by incorporating it into the semi-solid/ pasty melt. The subsequent overheating of the melt leads to an advanced assimilation of the scraps into the molten metal mass.

After the loading of each batch, the volatiles and the moisture in the chips/scraps evaporated after the contact with the hot bath and the remainder of the material was homogenized with the melt resulting in a viscous bath having a temperature of about $620^{\circ} \mathrm{C}$.

\section{Result and discussions}

From the thermodynamic studies of the reactions that can occur between the metal bath/chips and the reaction products between methane gas and oxygen, given the chemical composition of the secondary alloy studied, we have selected the following reactions as very probable.

$$
\begin{aligned}
& 2 \mathrm{Al}+3 \mathrm{H}_{2} \mathrm{O}(\mathrm{g})=\mathrm{Al}_{2} \mathrm{O}_{3}+3 \mathrm{H}_{2}(\mathrm{~g}) \\
& 2 \mathrm{Al}+3 \mathrm{CO}_{2}(\mathrm{~g})=\mathrm{Al}_{2} \mathrm{O}_{3}+3 \mathrm{CO}(\mathrm{g}) \\
& 2 \mathrm{Al}+1.5 \mathrm{O}_{2}(\mathrm{~g})=\mathrm{Al}_{2} \mathrm{O}_{3} \\
& 2 \mathrm{Mg}+\mathrm{O}_{2}(\mathrm{~g})=2 \mathrm{MgO}^{2} \\
& 2 \mathrm{Mn}+\mathrm{O}_{2}(\mathrm{~g})=2 \mathrm{MnO}
\end{aligned}
$$

Another category of reactions that may occur are those with the formation of complex compounds, between the aluminum oxides and the metal oxides in groups 1 and 2 of the Mendeleev Table (spinel), as can be deduced from the electron microscopy analysis and the EDS analysis presented in figure 5.
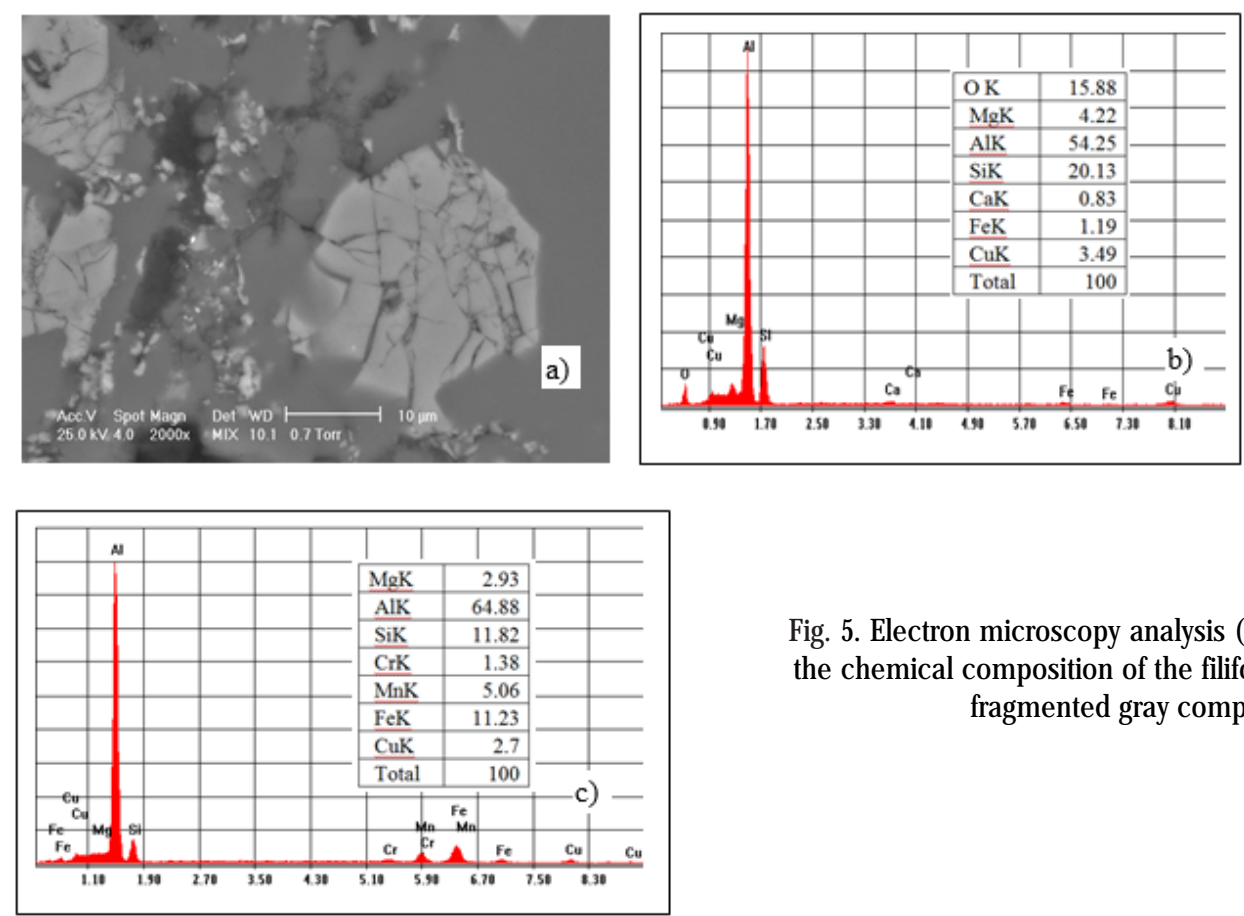

Fig. 5. Electron microscopy analysis (a) and EDS analysis with the chemical composition of the filiform compounds (b) and fragmented gray compounds (c) 
$2 \mathrm{Al}_{2} \mathrm{O}_{3}+2 \mathrm{Mg}+\mathrm{O}_{2}(\mathrm{~g})=2 \mathrm{MgAl}_{2} \mathrm{O}_{4}$ (ia)

$\mathrm{Ca}+2 \mathrm{Al}+2 \mathrm{O}_{2}(\mathrm{~g})=\mathrm{CaAl}_{2} \mathrm{O}_{4}(\mathrm{ia})$

$\mathrm{Ca}+2 \mathrm{Al}+4 \mathrm{CO}_{2}(\mathrm{~g})=\mathrm{CaAl}_{2} \mathrm{O}_{4}(\mathrm{ia})+4 \mathrm{CO}(\mathrm{g})$

$\mathrm{Mg}+2 \mathrm{Al}+4 \mathrm{CO}_{2}^{2}(\mathrm{~g})=\mathrm{MgAl}_{2} \mathrm{O}_{4}(\mathrm{ia})+4 \mathrm{CO}(\mathrm{g})$

\section{Activation energies of the reactions}

The dependencies of the speed constants of the temperature reactions $(1) \div(5)$ are represented in figures 6-10 and can be calculated with Arrhenius's equation:

$$
\mathrm{K}=\mathrm{Aexp}(-\mathrm{Q} / \mathrm{RT})
$$

where:

A represents the frequency factor;

$\mathrm{Q}$ is the activation energy of the reaction, $\mathrm{kJ} / \mathrm{mol}$;

$R$ is the universal gas constant;

$\mathrm{T}$ is the absolute temperature, $\mathrm{K}$.

By logarithm, it results:

$$
\ln K=\ln A+(1 / T)(-Q / R)
$$

The variation of the speed constant parameters in relation to temperature for each reaction is shown in tables (3-7).

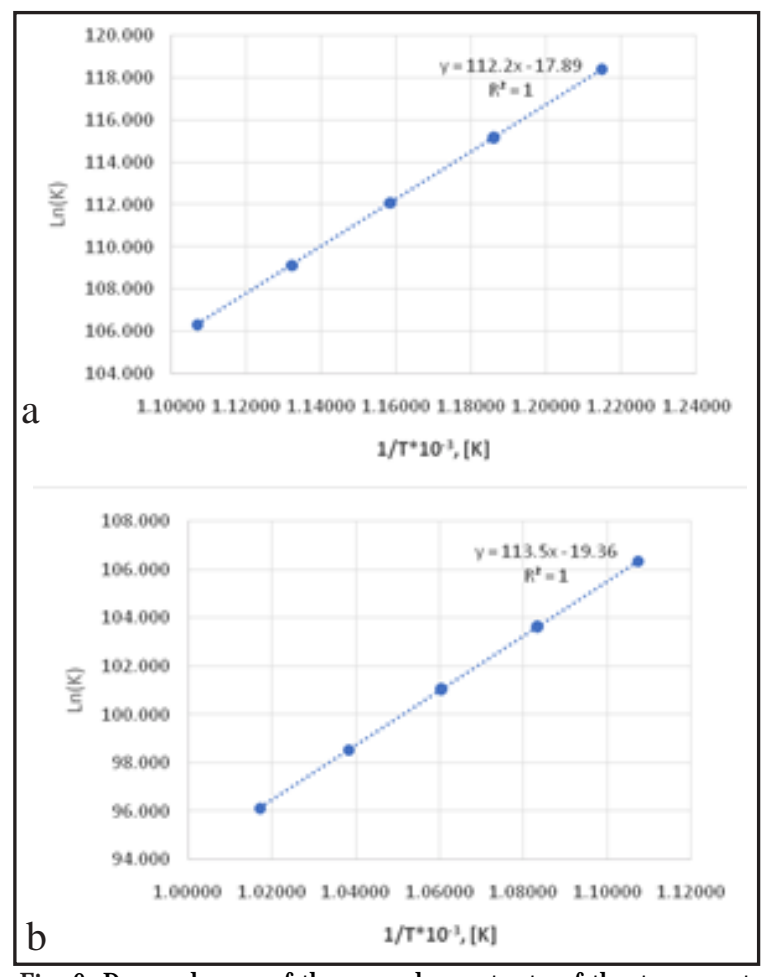

Fig. 6. Dependence of the speed constants of the temperature reaction 1 for the two intervals: a) 823.15 - $903.15 \mathrm{~K}$; b) 903.15 $983.15 \mathrm{~K}$

\begin{tabular}{|c|c|c|c|c|c|}
\hline $\mathrm{T}, \mathrm{K}$ & $\Delta \mathrm{G}, \mathrm{kJ}$ & $\mathrm{k}$ & $\ln \mathrm{k}$ & $1 / \mathrm{T}, \mathrm{K}^{-1}$ & $1 / \mathrm{T}^{*} 10^{-3}, \mathrm{~K}^{-1}$ \\
\hline 823.150 & -810.404 & $2.692 \mathrm{E}+051$ & 118.422 & 0.00121485 & 1.21485 \\
\hline 843.150 & -807.409 & $1.058 \mathrm{E}+050$ & 115.186 & 0.00118603 & 1.18603 \\
\hline 863.150 & -804.428 & $4.843 \mathrm{E}+048$ & 112.102 & 0.00115855 & 1.15855 \\
\hline 883.150 & -801.461 & $2.553 \mathrm{E}+047$ & 109.159 & 0.00113231 & 1.13231 \\
\hline 903.150 & -798.505 & $1.535 \mathrm{E}+046$ & 106.348 & 0.00110724 & 1.10724 \\
\hline 923.150 & -795.561 & $1.045 \mathrm{E}+045$ & 103.660 & 0.00108325 & 1.08325 \\
\hline 943.150 & -792.402 & $7.752 \mathrm{E}+043$ & 101.059 & 0.00106028 & 1.06028 \\
\hline 963.150 & -789.023 & $6.234 \mathrm{E}+042$ & 98.539 & 0.00103826 & 1.03826 \\
\hline 983.150 & -785.655 & $5.562 \mathrm{E}+041$ & 96.122 & 0.00101714 & 1.01714 \\
\hline
\end{tabular}

Table 3

VARIATION OF THERMODYNAMIC PARAMETERS BY TEMPERATURE FOR REACTION 1

Table 4 VARIATION OF THERMODYNAMIC PARAMETERS BY TEMPERATURE FOR REACTION 2
Fig. 7. Dependence of the speed constants of the temperature reaction 2 for the two intervals: a) $823.15-903.15 \mathrm{~K}$; b) $903.15-983.15 \mathrm{~K}$

1.100001.120001.140001.160001.180001.200001.220001.24000 $1 / \mathrm{T}^{*} 10^{-3},[\mathrm{~K}]$ 
Table 5

VARIATION OF THERMODYNAMIC PARAMETERS BY TEMPERATURE FOR REACTION 3

\begin{tabular}{|c|c|c|c|c|c|}
\hline $\mathrm{T}, \mathrm{K}$ & $\Delta \mathrm{G}, \mathrm{kJ}$ & $\mathrm{k}$ & $\ln \mathrm{k}$ & $1 / \mathrm{T}, \mathrm{K}^{-1}$ & $1 / \mathrm{T}^{*} 10^{-3}, \mathrm{~K}^{-1}$ \\
\hline 823.150 & -1417.438 & $8.992 \mathrm{E}+089$ & 207.126 & 0.00121485 & 1.21485 \\
\hline 843.150 & -1411.220 & $2.722 \mathrm{E}+087$ & 201.326 & 0.00118603 & 1.18603 \\
\hline 863.150 & -1405.006 & $1.079 \mathrm{E}+085$ & 195.795 & 0.00115855 & 1.15855 \\
\hline 883.150 & -1398.794 & $5.492 \mathrm{E}+082$ & 190.515 & 0.00113231 & 1.13231 \\
\hline 903.150 & -1392.585 & $3.535 \mathrm{E}+080$ & 185.469 & 0.00110724 & 1.10724 \\
\hline 923.150 & -1386.378 & $2.832 \mathrm{E}+078$ & 180.642 & 0.00108325 & 1.08325 \\
\hline 943.150 & -1379.947 & $2.705 \mathrm{E}+076$ & 175.992 & 0.00106028 & 1.06028 \\
\hline 963.150 & -1373.286 & $3.047 \mathrm{E}+074$ & 171.505 & 0.00103826 & 1.03826 \\
\hline 983.150 & -1366.629 & $4.120 \mathrm{E}+072$ & 167.202 & 0.00101714 & 1.01714 \\
\hline
\end{tabular}

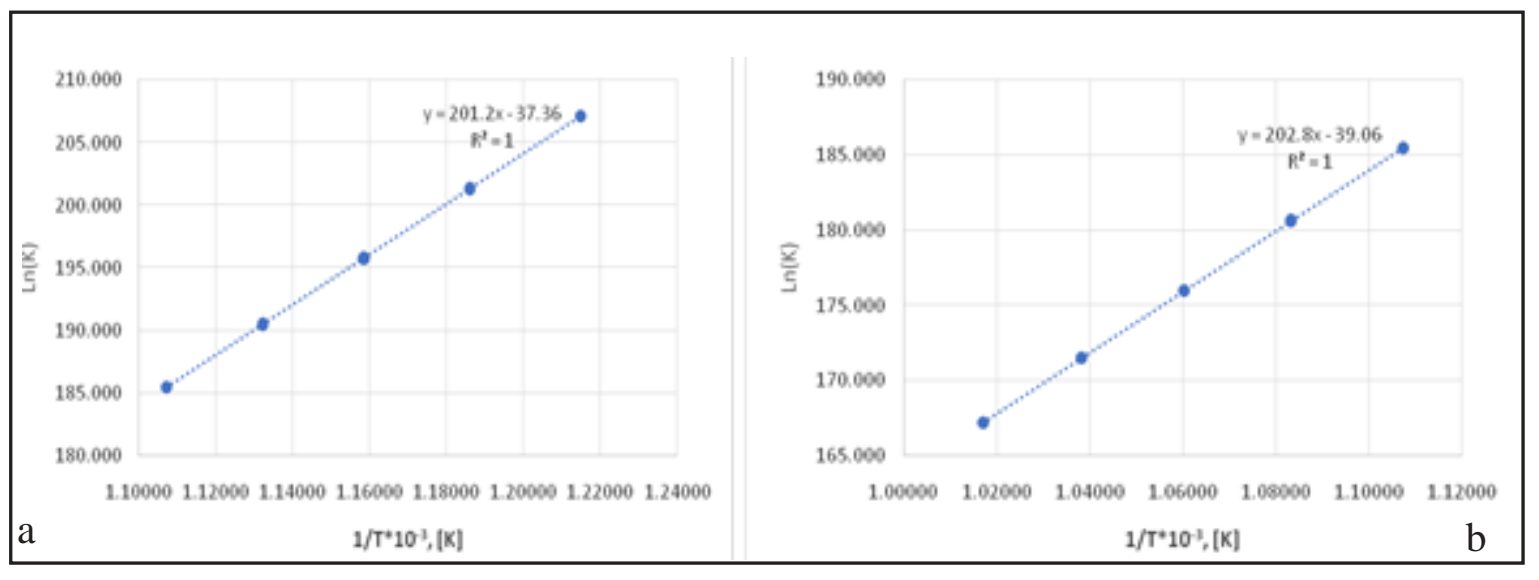

Fig. 8. Dependence of the speed constants of the temperature reaction 3 for the two intervals: a) $823.15-903.15 \mathrm{~K}$; b) $903.15-983.15 \mathrm{~K}$

Table 6 VARIATION OF THERMODYNAMIC PARAMETERS BY TEMPERATURE FOR REACTION 4

\begin{tabular}{|c|c|c|c|c|c|}
\hline $\mathrm{T}, \mathrm{K}$ & $\Delta \mathrm{G}, \mathrm{kJ}$ & $\mathrm{k}$ & $\ln \mathrm{k}$ & $1 / \mathrm{T}, \mathrm{K}^{-1}$ & $1 / \mathrm{T}^{*} 10^{-3}, \mathrm{~K}^{-1}$ \\
\hline 823.150 & -1025.971 & $1.290 \mathrm{E}+065$ & 149.922 & 0.00121485 & 1.21485 \\
\hline 843.150 & -1021.719 & $2.007 \mathrm{E}+063$ & 145.760 & 0.00118603 & 1.18603 \\
\hline 863.150 & -1017.469 & $3.790 \mathrm{E}+061$ & 141.790 & 0.00115855 & 1.15855 \\
\hline 883.150 & -1013.220 & $8.566 \mathrm{E}+059$ & 138.000 & 0.00113231 & 1.13231 \\
\hline 903.150 & -1008.973 & $2.290 \mathrm{E}+058$ & 134.379 & 0.00110724 & 1.10724 \\
\hline 923.150 & -1004.723 & $7.162 \mathrm{E}+056$ & 130.914 & 0.00108325 & 1.08325 \\
\hline 943.150 & -1000.109 & $2.476 \mathrm{E}+055$ & 127.549 & 0.00106028 & 1.06028 \\
\hline 963.150 & -995.493 & $9.845 \mathrm{E}+053$ & 124.324 & 0.00103826 & 1.03826 \\
\hline 983.150 & -990.877 & $4.462 \mathrm{E}+052$ & 121.230 & 0.00101714 & 1.01714 \\
\hline
\end{tabular}

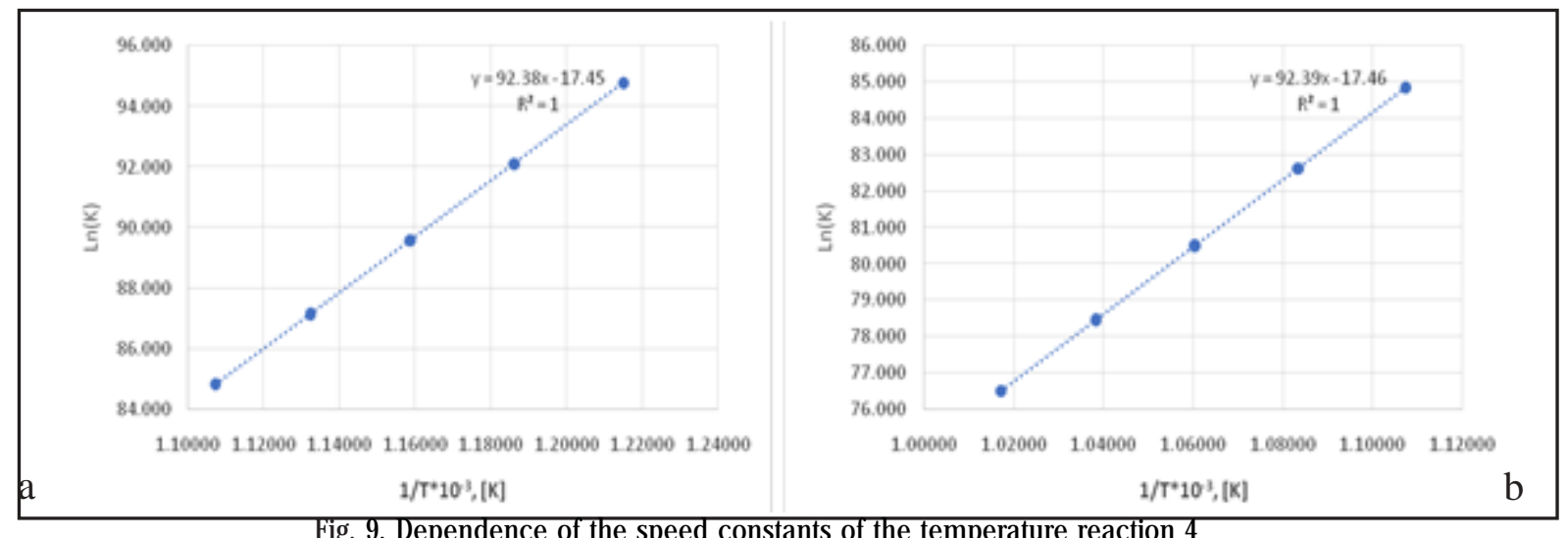

Fig. 9. Dependence of the speed constants ot the temperature reaction 4 for the two intervals: a) 823.15 - $903.15 \mathrm{~K}$; b) 903.15 - $983.15 \mathrm{~K}$ 
Table 7

VARIATION OF THERMODYNAMIC PARAMETERS BY TEMPERATURE FOR REACTION 5

\begin{tabular}{|c|r|r|r|r|c|}
\hline $\mathrm{T}, \mathrm{K}$ & $\Delta \mathrm{G}, \mathrm{kJ}$ & $\mathrm{k}$ & $\ln \mathrm{k}$ & $1 / \mathrm{T}, \mathrm{K}^{-1}$ & $1 / \mathrm{T}^{*} 10^{-3}, \mathrm{~K}^{-1}$ \\
\hline 823.150 & -648.604 & $1.452 \mathrm{E}+041$ & 94.779 & 0.00121485 & 1.21485 \\
\hline 843.150 & -645.702 & $1.013 \mathrm{E}+040$ & 92.117 & 0.00118603 & 1.18603 \\
\hline 863.150 & -642.800 & $8.001 \mathrm{E}+038$ & 89.578 & 0.00115855 & 1.15855 \\
\hline 883.150 & -639.899 & $7.088 \mathrm{E}+037$ & 87.154 & 0.00113231 & 1.13231 \\
\hline 903.150 & -636.998 & $6.991 \mathrm{E}+036$ & 84.838 & 0.00110724 & 1.10724 \\
\hline 923.150 & -634.097 & $7.624 \mathrm{E}+035$ & 82.622 & 0.00108325 & 1.08325 \\
\hline 943.150 & -631.197 & $9.132 \mathrm{E}+034$ & 80.500 & 0.00106028 & 1.06028 \\
\hline 963.150 & -628.296 & $1.195 \mathrm{E}+034$ & 78.466 & 0.00103826 & 1.03826 \\
\hline 983.150 & -625.379 & $1.695 \mathrm{E}+033$ & 76.513 & 0.00101714 & 1.01714 \\
\hline
\end{tabular}

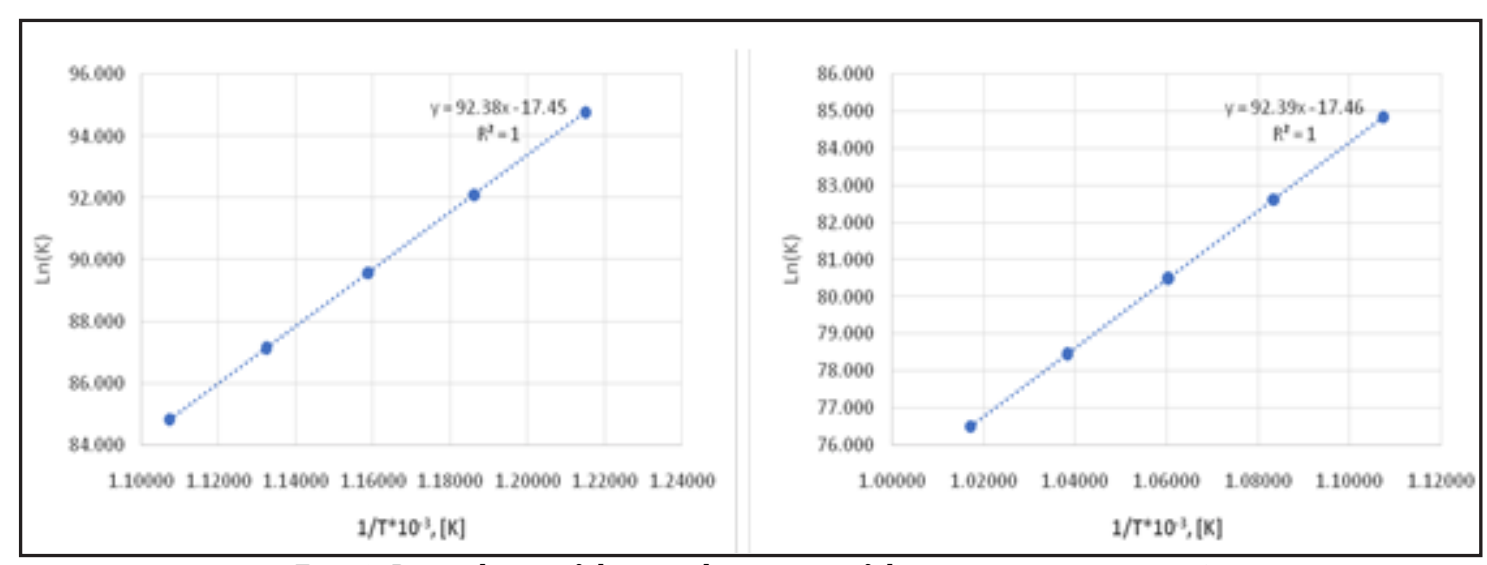

Fig. 10. Dependence of the speed constants of the temperature reaction 5

for the two intervals: a) 823.15 - $903.15 \mathrm{~K}$; b) 903.15 - $983.15 \mathrm{~K}$

Table 8

VARIATION OF ACTIVATION ENERGIES (Q) FOR THE REACTIONS (1) $\div$ (5)

\begin{tabular}{|c|c|c|c|c|c|}
\hline Reaction & Temperature, K & $\ln A$ & $A$ & $-Q / R$ & $Q, \mathrm{~kJ} / \mathrm{mol}$ \\
\hline \multirow{3}{*}{1} & $823.15-903.15$ & 112.2 & 4.720283 & -17.89 & 0.148746 \\
\cline { 2 - 6 } & $903.15-983.15$ & 113.5 & 4.731802 & -19.36 & 0.160968 \\
\hline \multirow{2}{*}{2} & $823.15-903.15$ & 99.1 & 4.596129 & -5.779 & 0.048049 \\
\cline { 2 - 6 } & $903.15-983.15$ & 100.7 & 4.612145 & -7.581 & 0.063032 \\
\hline \multirow{2}{*}{3} & $823.15-903.15$ & 201.2 & 5.304299 & -37.36 & 0.310630 \\
\cline { 2 - 6 } & $903.15-983.15$ & 202.8 & 5.312220 & -39.06 & 0.324764 \\
\hline \multirow{2}{*}{4} & $823.15-903.15$ & 144.4 & 4.972587 & -25.55 & 0.212435 \\
\cline { 2 - 6 } & $903.15-983.15$ & 146.0 & 4,983606 & -27.29 & 0.226902 \\
\hline \multirow{2}{*}{5} & $823.15-903.15$ & 92.38 & 4.525911 & -17.45 & 0.145088 \\
\cline { 2 - 6 } & $903.15-983.15$ & 92.39 & 4.526018 & -17.46 & 0.145171 \\
\hline
\end{tabular}

For reactions $(1) \div(5)$, for temperature ranges, 823.15 - $903.15 \mathrm{~K}\left(550-630^{\circ} \mathrm{C}\right)$ and $903.15-983.15 \mathrm{~K}\left(630-710^{\circ} \mathrm{C}\right)$, result in the following values for the frequency factors $(A)$ and activation energies (Q) (table 8).

\section{Conclusions}

The processing of small metallic waste at high temperatures leads to significant losses of both aluminum as well as the metals that are part of the secondary alloys. The losses are even higher as the quality of the materials used is lower.

The proposed technology consists of processing the small waste at low temperatures $\left(580 \div 620^{\circ} \mathrm{C} / 853.15 \div\right.$ $893.15 \mathrm{~K}$ for the EN AB 46100 alloy), temperatures near the eutectic temperature of the said alloy.

Using an intermediate step in the technological process -oxygen only feeds, stage after loading the furnace with a new amount of waste, leads to the reduction of natural gas consumption by burning volatile substances from preheating waste composition.
For reactions $(1) \div(5)$, values of free enthalpy (Gibbs energy) have very high values in absolute value, which means that all these reactions take place from left to right (for example, at a temperature of $610^{\circ} \mathrm{C} / 883.15 \mathrm{~K}: \mathrm{DG}=$ $-801.461 \mathrm{~kJ}, \mathrm{DG}_{2}=-824.018 \mathrm{~kJ}$ and $\left.\mathrm{DG}_{3}=-1398.794 \mathrm{~kJ}\right)$.

The reaction activation energy $(\mathrm{Q})$ exhibits higher values for the $630 \div 710^{\circ} \mathrm{C} / 903.15-983.15 \mathrm{~K}$ temperature range, than the $550 \div 630^{\circ} \mathrm{C} / 823.15-903.15 \mathrm{~K}$ interval. The phenomenon that occurs and leads to an increase in activation energy is oxidation of the scrap surface, a phenomenon which subsequently leads to an increase in the amount of slag resulting in the production of secondary alloys with aluminium base, using small waste.

\section{References}

1. M.C. SHINZATO, R. HYPOLITO, Solid waste from aluminum recycling process: characterization and reuse of its economically valuable constituents, Waste Management 25 (2005) p. 37-46. 
2. P.E. TSAKIRIDIS, P. OUSTADAKIS, S. AGATZINI-LEONARDOU, Aluminium recovery during black dross hydrothermal treatment, J ournal of Environmental Chemical Engineering 1 (2013) p. 23-32.

3. E. DAVID, J. KOPAC, Aluminum recovery as a product with high added value using aluminum hazardous waste, Journal of Hazardous Materials 261 (2013) p. 316-324.

4. ABDURAHIM ABDULKADIR, ADESOLA AJ AYI, MOHAMEDI. HASSAN, Evaluating the Chemical Composition and the Molar Heat Capacities of a white Aluminum Dross, Energy Procedia 75 (2015) p. 2099-2105. 5. H.N. YOSHIMURA, A.P. ABREU, A.L. MOLISANI, A.C. DE CAMARGO, J.C.S. PORTELA, N.E. NARITA, Evaluation of aluminum dross waste as raw material for refractories, Ceramics International 34 (2008) $p$. 581-591.

6. APENG LI, HAIJUN ZHANG, HUAMING YANG, Evaluation of aluminum dross as raw material for high-alumina refractory, Ceramics International 40 (2014), p. 12585-12590.

7. E. BLONDEEL, M. CHYS, V. DEPUYDT, K. FOLENS, G. DULAING, A. VERLIEFDE, S.W.H. VAN HULLE, Leaching behaviour of different scrap materials at recovery and recycling companies: Full-pilot- and labscale investigation, Waste Management 34 (2014) p. 2674-2686.

8. HONG JIAN-PING, WANG JUN, CHEN HAI-YAN, SUN BAO-DE, LI J IAJING, CHEN CHONG, Process of aluminum dross recycling and life cycle assessment for Al-Si alloys and brown fused alumina, Trans. Nonferrous Met. Soc. China 20(2010) p. 2155-2161.

9.B.R. DAS, B. DASH, B.C. TRIPATHY, I.N. BHATTACHARYA, S.C. DAS, Production of h-alumina from waste aluminium dross, Minerals Engineering 20 (2007) p. 252-258.
10.NORIHIRO MURAYAMA, IKUO MAEKAWA, HIROYUKI USHIRO, TAKAYUKI MIYOSHI, JUNJI SHIBATA, MARJORIE VALIX, Synthesis of various layered double hydroxides using aluminum dross generated in aluminum recycling process, International Journal of Mineral Processing 110-111 (2012) p. 46-52.

11. E.M.M. EWAIS, N.M. KHALIL, M.S. AMIN, Y.M.Z. AHMED, M.A. BARAKAT, Utilization of aluminum sludge and aluminum slag (dross) for the manufacture of calcium aluminate cement, Ceramics International 35 (2009) p. 3381-3388.

12. B. DASH, B.R. DAS, B.C. TRIPATHY, I.N. BHATTACHARYA, S.C. DAS, Acid dissolution of alumina from waste aluminium dross, Hydrometallurgy 92 (2008) p. 48-53.

13. P.E. TSAKIRIDIS, Aluminium salt slag characterization and utilization - A review, J ournal of Hazardous Materials 217-218 (2012) p. 1-10.

14. XIAO-LAN HUANG, AMRO EL BADAWY, MAHENDRANATH ARAMBEWELA, ROBERT FORD, MORTON BARLAZ, THABET TOLAYMAT, Characterization of salt cake from secondary aluminum production, Journal of Hazardous Materials 273 (2014) p. 192-199.

15. D. BAJARE, A. KORJAKINS, J. KAZJ ONOVS, I. ROZENSTRAUHA, Pore structure of lightweight clay aggregate incorporate with nonmetallic products coming from aluminium scrap recycling industry, J ournal of the European Ceramic Society 32 (2012) p. 141-148.

16. M. BUTU, C. APOSTOL, M. SCRIPCARIU, I.M. BUTU, R. PORUMB, I. BITIR ISTRATE, I. UNGUREANU, C.D. STÃNCEL, Thermodynamic investigation of oxygen/natural gas combustion in secondary aluminum technology, U.P.B. Sci. Bull. Series B, Vol. 80, Iss.,2, 2018, p. 213-226.

17. ***Sidermes, General ALU-DELTA operating instructions. 18. ***https://www.tms.org/Scrap_Specifications_Circular.pdf.

Manuscript received: 6.02 .2018 